\title{
MANAJEMEN KARAKTER PESERTA DIDIK MELALUI KETERAMPILAN MENULIS KRITIS
}

\author{
Yasinta Mahendra \\ STKIP Muhammadiyah Kotabumi \\ yasinta.mahendra2014@gmail.com
}

\begin{abstract}
Abstrak
Manajemen adalah proses yang dikerjakan untuk mencapai tujuan, baik perorangan maupun organisasi. Sedangkan karakter sendiri bermakna watak, tabiat, atau sifatsifat kejiwaan yang ada dalam diri seseorang, dapat berasal dari keturunan atau ada faktor lain yang dapat mempengaruhi kakater itu sendiri. Karakter berpengaruh pada model fikiran yang akan dihasilkan seseorang nantinya dalam berfikir dan menentukan sikap. Maka sebaiknya karakter harus di bentuk sejak usia sedini mungkin agar setiap anak terbiasa dengan pola fikir yang positif namun kritis. Kesalahan dalam mendidik anak dapat berakibat pada rendahnya karakter yang dimiliki anak. Menulis adalah penyampaian pesan dengan menggunakan bahasa tulis sebagai medianya. Keterampilan menulis dikuasai hampir sebagian besar orang terutama dalam dunia akademisi, karena kaum akademisi biasnya dikenal dengan istilah kaum intelektual dan identik dengan kritis. Untuk itu ada korelasinya antara menulis kritis dengan manajemen karakter peserta didik, yang diharapkan nantinya pembelajaran menulis kritis ini dapat menguatkan karakter yang ada dalam diri setiap peserta didik.
\end{abstract}

Kata Kunci : Manajemen, Menulis Kritis, Karakter 


\section{PENDAHULUAN}

Manajemen karakter peserta didik adalah salah satu aspek penting yang harus diperhatikan oleh pendidik dan orang tua. Mengapa demikian? Pertanyaan ini sering muncul dalam benak kita. Saat ini muncul istilah krisis karakter,bangsa ini seperti kehilangan jati diri dikarenakan pembentukan karakter yang lemah oleh sebab itulah manajemen karakter harus dibentuk sedini mungkin, agar kita tidak kehingan jati diri sebagai bangsa, karakter yang kuat dapat berpengaruh pada dasar pemikiran yang sehat.

Setelah itu lalu munucul mengapa menulis kritis perlu dipelajari1 Dalam menulis kritis sesungguhnya telah terjadi dua proses sekaligus yaitu proses cara berfikir kritis dan pembentukan karakter. Ada istilah yang mengatakan bahwa ada kalanya mata pena akan lebih tajam daripada mata pisau,hal ini menunjukkan bahwa menulis dapat menumbukan rasa berani dan kritis mengenai padangan yang ada di dalam dirinya mengenai suatu hal. Mengapa hal itu dapat terjadi, itu terjadi karena tidak semua orang memiliki keterampilan berbicara yang baik, untuk itu menulis adalah satu-satunya cara untuk mengungkapkan pendapat yang ada dalam diri seseorang, walaupun dalam proses menulis seseorang masih terkendala dalam proses kebuntuan dalam berfikir. Hal tersebut terjadi karena penulis sering bingung dalam menentukan apakah tulisan yang dibuatnya adalah tulisan kritis atau kreatif. Hal yang paling sering terjadi selama ini adalah ketika seseorang mulai untuk menulis beberapa kalimat, seseorang akan langsung menghapusnya (melakukan editing) padahal seharusnya hal ini tidak dilakukan dalam proses menulis kritis.

Menulis kritis adalah menyampaikan pandangannya dengan cara kritis, sedangan menghapus kata-kata yang telah terusun bukanlah ciri menulis kritis itu adalah cara menulis kreatif 2. Dampaknya seseorang kembali akan kehilangan karakter yang perlahan tumbuh dalam dirinya, karena semakin sering seseorang menghapus tulisanya maka sesorang tersebut akan kehilangan pola fikir yang telah di dapatkannya, sehingga sering kali tulisan seseorang tidak beraturan atau bahkan menyimpang dari ide yang sejak awal 3 di gagasnya, padahal jika seseorang faham ketika seseorang memulai menulis kritis maka otomatis ia akan memulai menulis kreatif. Mengapa demikian? Karena orang yang terbiasa menulis krtis akan santun dalam menyampaikan gagasan dan ide dalam fikiranya yang akan ia tuangkan dalam tulisan. Dalam hal ini tugas menulis kritis adalah mengajarkan bagaimana mengkritisi segala sesuatu yang perlu dikritisi namun dalam bentuk tulisan yang apik. Sehingga

1 Kompri, Manajemen Pendidikan 1 (Bandung, Alfabeta,2015) hlm. 5

2 Dalman, Keterampilan Menulis (Depok, Raja Grafindo, 2018) hlm. 15 
karakter dalam diri peserta didik terbentuk dengan sendirinya melalui goresangoresan tulisan bernada kritis untuk membangun namun santun.

\section{PEMBAHASAN}

\section{Keterampilan Menulis}

Bahasa hakikatnya berfungsi sebagai alat komunikasi masal, dalam era reformasi saat ini bahasa berperan penting yang dipergunakan dalam proses interaksi dalam bersosialisasi sesama mahluk hidup. Hal ini senada dengan pendapat yang disampaikan oleh Daoed Joesoef (dalam Minto Rahayu 2007:5) ${ }^{1}$ "Bangsa yang telah maju peradabannya ditandai tidak saja oleh kemampuannya menguasai alam, membangun industri berat, membuat jaringan jalan raya, dan sistem pelayanan jasa yang bermutu tinggi, tetapi juga oleh tingkat pemakaian bahasa dalam keanekaragaman kehidupan.4"

Dalam mengunakan bahasa seseorang harus memiliki keterampilan dasar agar dapat berbahasa dengan baik dan benar sesuai dengan konteksnya. Keterampilan berbahasa tersebut memiliki peranan yang penting di dalam proses kehidupan bermasyarakat. Salah satu aspek keterampilan berbahasa yang harus dikuasai adalah keterampilan menulis.

Dengan menguasai keterampilan menulis, seseorang dapat mengungkapkan pikiran dan gagasan untuk mencapai maksud dan tujuan apa yang hendak disampaikan dengan baik.

Dari penjelasan di atas dapat disimpulkan bahwa keterampilan menulis adalah keterampilan yang sangat kompleks dalam keterampilan berbahasa, karena keterampilan menulis adalah suatu proses perkembangan yang menuntut pengalaman, waktu, kesepakatan, latihan serta memerlukan cara berpikir yang teratur untuk mengungkapkannya kembali ke dalam bentuk bahasa tulis yang apik. Oleh karena itu, sudah selayaknya keterampilan menulis mendapat perhatian yang lebih khusus sebagai salah satu aspek keterampilan dalam berbahasa.

\section{Hakikat Menulis}

Kata menulis berasal dari kata dasar tulis yang mendapat imbuhan me. Imbuhan me- di sini menyatakan pekerjaan, sehingga menulis bermakna melakukan pekerjaan tulis. Sedangkan jika dilihat dari hakikatnya, menulis adalah menurunkan atau melukiskan lambang-lambang grafik yang menggambarkan suatu bahasa yang dipahami oleh seseorang, sehingga orang lain dapat membaca lambang grafik tersebut kalau mereka memahami bahasa dan gambaran grafik tersebut (Tarigan 2000:21).

Sementara pendapat lain datang dari Wagiran dan Doyin (2005:2) yang menyatakan bahwa hakikat menulis merupakan salah satu keterampilan

4 Rahayu Minto, Bahasa Indonesia di Perguruan Tinggi (Jakarta, Grasindo 2018) hlm. 107 
berbahasa yang dipergunakan dalam komunikasi secara tidak langsung. Keterampilan menulis tidak didapatkan secara alamiah dan instan, melainkan harus melalui proses belajar dan berlatih dengan sungguh-sungguh. Menulis sifatnya adalah keterampilan berbahasa yang produktif dan reseptif. Dalam kegiatan ini, penulis harus terampil menggunakan diksi/pilihan kata, struktur kalimat, pola pengembangan paragraf, dan logika berbahasa5.

Dalam kegiatan menulis dapat disebut dengan bentuk manifestasi kemampuan berbahasa yang paling akhir dikuasai siswa setelah kemampuan mendengarkan, berbicara, dan membaca. Dalam hal itu dibandingkan dengan tiga kemampuan berbahasa yang lain, menulis lebih sulit dikuasai. Lebih jauh dijelaskan pula bahwa kemampuan menulis menghendaki penguasaan berbagai unsur kebahasaan dan unsur di luar bahasa itu sendiri yang akan menjadi isi tulisan6.

Jadi dapat disimpulkan bahwa pada hakikatnya menulis adalah melukiskan lambang grafis yang dimengerti oleh penulis untuk menuangkan ide-ide, pengalaman, perasaan, pendapat, atau pengetahuan yang dapat dijadikan sebagai salah satu sarana untuk berkomunikasi secara tidak langsung atau tertulis.

Jika pengungkapan gagasan itu tepat maka pesan yang akan disampikan dalam menulis akan tersampaikan dengan baik. Hal lain selain komponen kosakata dan gramatikal, ketepatan pengunaan diksi juga sebaiknya didukung oleh konteks dan penggunaan ejaan.

\section{Tujuan Menulis}

Menulis memiliki tujuan khusus yaitu mengungkapkan fakta-fakta, perasaan, sikap, dan isi pikiran secara jelas dan efektif kepada pembaca. Dengan kegiatan menulis ini diharapkan dapat meningkatkan kecerdasan, mengembangkan daya inisiatif dan kreativitas, menumbuhkan keberanian dan mendorong kemauan, serta kemampuan untuk mengumpulkan informasi7. Ada beberapa tujuan menulis di antaranya adalah :

a) memberi informasi, yakni menyampaikan fakta-fakta mengenai peristiwa, masalah, tren, atau fenomena,

b) menjelaskan tulisan yang menganalisis/menguraikan mengapa suatu peristiwa, masalah, tren, atau fenomena terjadi (biasanya memaparkan peristiwa, masalah, tren, atau fenomena, sehingga khalayak memahaminya), c) mengarahkan tulisan "Seperti Ini"/tips dalam mengerjakan suatu hal ("How To" Article).

5 Nurgiyantoro, Keterampilan Menulis (Jakarta, Gramedia 2007) HIm. 273

$6 \mathrm{Ibid}, \mathrm{hlm} .120$

7 lbid, hlm. 127 
d) membujuk/meyakinkan orang, tulisan ini mencoba mempersuasi orang atau setidaknya memiliki pemikiran yang sebanding tentang peristiwa, masalah, tren, atau fenomena, seperti misalnya tulisan resensi buku atau film, dan

e) meringkaskan/membuat suatu rangkuman dari suatu karya (buku, dsb.), sebuah kegiatan, rapat, atau seminar menjadi lebih ringkas dan bisa dibaca dengan cepat tanpa kehilangan intisarinya.

Jadi dapat disimpulkan bahwa tujuan menulis adalah untuk mengungkapkan fakta-fakta, perasaan, sikap, isi pikiran, memberi informasi, memaparkan suatu kejadian, mempengaruhi pembaca, mengungkapkan ide, pikiran, gagasan, dan pengetahuan penulis kepada pembaca. Menulis juga memiliki fungsi yaitu sebagai alat komunikasi yang tidak langsung. Ada beberapa fungsi dari tulisan yaitu:

1. Menolong kita berpikir secara kritis;

2. Memudahkan kita merasakan dan menikmati hubungan-hubungan;

3. Memperdalam daya tanggap atau persepsi kita;

4. Memecahkan masalah-masalah yang kita hadapi;

5. Menyusun urutan bagi pengalaman;

6. Membantu kita menjelaskan pikiran-pikiran;

7. Dll.

\section{Manfaat Menulis}

Menulis memiliki banyak manfaat, baik untuk ilmu penegetahuan maupun bagi kesehatan. Ada beberapa ahli yang berpendapat tentang manfaat menulis. Bahkan beberapa ahli mengatakan bahawa menulis dapat menjernihkan pikiran, menghilangkan trauma, mendapatkan dan menggali informasi-informasi baru, membantu menyelesaikan masalah, dan membantu seseorang menulis ketika terpaksa harus menulis.

Bahkan dalam jurnal Clinical Psychology, dikatakan bahwa orang yang memiliki kebiasaan menulis umumnya memiliki kondisi mental lebih sehat dari mereka yang tidak mempunyai kebiasaan tersebut. Timbulnya pikiran yang sehat tentunya akan memiliki kekuatan untuk memberi dampak positif pada tubuh kita secara fisik.Sementara itu menulis juga menimbulkan rasa ingin tahu (curiocity) dan melatih rasa peka dalam melihat realitas keadaan sekitar lingkungan, mendorong kita untuk tidak malas dalam hal untuk mencari referensi seperti buku, majalah, koran, jurnal, dan sejenisnya, berusaha berlatih untuk menyusun pemikiran dan argumen secara runtut, sistematis, dan logis, serta yang paling penting menulis secara psikologis akan mengurangi tingkat ketegangan dan stress. 
Dengan demikian, dapat disimpulkan bahwa kegiatan menulis sangat besar manfaatnya, baik dalam dunia pendidikan maupun kesehatan8. Dekan frekwensi semakin sering menulis maka dapat menghasilkan ide-ide baru atau kreatif, dan menulis dapat dijadikan sebagai alat evaluasi serta pemecahan masalah. Dengan menulis, juga dapat menumbuhkan pemikiran yang kritis dan lebih teliti dalam memproses informasi lebih banyak sehingga wawasan dan pengetahuannya akan semakin bertambah.

\section{Menulis Kritis}

Menulis juga dapat mendorong kita untuk berpikir secara kritis, memudahkan penulis memahami hubungan gagasan dalam tulisan, memperdalam daya tanggap atau persepsi, memecahkan masalah yang dihadapi, dan mampu menambah pengalaman menulis. Kata dasar kritik berasal dari kata Perancis yang berarti penilaian kritis, baik itu penilaian secara positif, negatif, atau campuran keduanya. Secara umum kritik ini sangat luas ruang lingkupnya. Salah satu jenis kritikan yang umum adalah dalam hal menulis. Menulis kritis memiliki berbagai struktur, tetapi yang paling sederhana adalah ringkasan pendek dan evaluasi mengenai suatu hal yang perlu atau di anggap penting untuk di kritisi.

Dalam hal menulis kritis tidak dibatasi subsatansi/ perorangan yang akan di kritisi, yang terpenting adalah dapat memberikan kritik yang dapat membangun. 9Dalam beberapa bidang studi, menulis kritis dapat membngun jiwa kepemimpinan khusnya jiwa berani, berani dalam mengungkapkan ide, pendapat, gagasan tentang segala sesuatu yang berhubungan dengan perbaikan, dalam bentuk tulisan. Salah satu cara untuk memberikan kritisi dalam bentuk tulisan adalah sebagai berikut :

1. Sebelum menulis kritis penulis harus memastikan bahwa objek yang akan dikritisi benar-benar tepat sasaran bukan abstrak.

2. Penulis harus jeli melihat hal apa saja yang dapat di jadikan sasaran kritik dalam penulisan, fokuskan pada salah satu hal misalnya, mengenai kinerja seseorang, kepemimpinan seseorang, serta objek lainnya.

3. Pastikan bahwa isi tulisan yang bernada kritis dapat menciptakan suatu hal yang positif dan bersifat membangun.

4. Dll.

Menulis kritis mengharuskan penulis belajar untuk mengekspresikan diri melalui komentar evaluatif di bidang yang sesuai dengan standar penilaian yang akan dilakukan. Hal ini penting karena kritikan akan menjadi "adil dan masuk akal." Dikatakan "adil" karena sesuatu yang logis dalam satu bidang seharusnya tidak diterapkan pada bidang lain dimana kriteria tersebut bisa saja

$8 \mathrm{lbid}, \mathrm{h} .220$

9 Dalman, Op. Cit. hlm . 79 
tidak masuk akal. Sebagai contoh, dalam hal bagaimana perlunya pengawasan dari pimpinan terhadap kedisiplinan kerja karyawan.

Kita juga harus mencatat pada tahap kritik pada bidang yang berbeda cenderung memaksakan perbedaan penekanan pada kritikan yang akan dilakukan. Dalam ilmu humaniora, perhatian kita mungkin terfokus pada bagaimana sebuah argumen dalam tulisan diciptakan agar "menarik". Ada beberapa syarat dalam menulis kritis yaitu :

1. Memiliki kemampuan membaca analitis.

2. Memiliki pengalaman dalam menulis

3. Familiar dengan peran dan tempat atau kualifikasi bacaan yang akan di kritik.

4. Menumbuhkan rasa dalam diri sebagai pemberi kritikan yang bersifat membangun bukan menjatuhkan.

5. Dapat menampilkan jati diri Anda dalam tulisan sendiri sebagai orang yang mengusai bidang disiplin ilmu yang akan d kritik.

Dalam menulis kritis, kita perlu untuk mengekspresikan kritikan dengan mengatakan perbaikan apa yang seharusnya dilakukan.

\section{Definisi Karakter}

Menurut Kamus Besar Bahasa, karakter adalah tabiat atau kebiasaan. Sedangkan menurut ahli psikologi, karakter adalah sebuah sistem keyakinan dan kebiasaan yang mengarahkan tindakan seorang individu10.

Oleh sebab itu, jika pengetahuan mengenai karakter seseorang itu dapat di ukur dan diketahui, maka dapat diketahui pula bagaimana individu tersebut bersikap untuk menghadapi kondisi-kondisi tertentu. Dilihat dari pengertiannya ternyata karakter dan akhlak tidak memiliki perbedaan yang jauh. Keduanya artikan sebagai suatu tindakan yang terjadi tanpa ada lagi pemikiran lagi karena sudah tertanam dalam pikiran, dan dengan kata lain, keduanya dapat disebut dengan kebiasaan atau tabiat.

\section{a. Unsur dalam Pembentukan Karakter}

Dalam membentuk karakter hal terpenting yang harus dilakukan adalah pikiran, karena di dalam fikiran terdapat seluruh program yang terbentuk dari pengalaman hidupnya, hal itulah yang merupakan pelopor segalanya. Kedua hal inilah yang kemudian membentuk sistem kepercayaan yang akhirnya dapat membentuk pola berpikir seseorang yang nantinya bisa mempengaruhi perilakunya.

Jika pola fikir yang tertanam tersebut sesuai dengan prinsip-prinsip kebenaran universal, maka perilakunya berjalan selaras dengan hukum alam

10 Koesoema. Doni A, Pendidikan Karakter Strategi Mendidik Anak di Zaman Global (Jakarta: Grasindo 2010) hlm 78 
dan hasil dari perilaku tersebut membawa ketenangan dan kebahagiaan. Sebaliknya, jika pola fikir tersebut tidak sesuai dengan prinsip-prinsip hukum universal, maka hal yang timbul dari perilakunya membawa kerusakan dan menghasilkan penderitaan baik bagi dirinya maupun orang lain. Oleh karena itu, pola fikir harus mendapatkan perhatian khusus dari setiap orang.

Akal/pola fikiran sadar yang secara fisik terletak di bagian korteks, otak yang bersifat logis dan analisis dengan memiliki pengaruh sebesar $12 \%$ dari kemampuan otak. Sedangkan pikiran bawah sadar secara fisik terletak di medulla oblongata, fikiran bawah sadar inilah yang sudah terbentuk ketika masih di dalam kandungan, itulah alas an mengapa ketika bayi yang dilahirkan menangis, bayi tersebut akan tenang di dekapan ibunya karena dia sudah merasa tidak asing lagi dengan detak jantung ibunya. Pikiran bawah sadar itulah yang telah diwarisi bayi pada saat berada di dalam kandungan 11. Untuk memahami cara kerja pikiran, kita perlu mengetahui bahwa pikiran sadar (conscious) adalah pikiran objektif yang berhubungan dengan objek luar, dengan bantuan menggunakan panca indra sebagai media dan sifat pikiran sadarnya adalah menalar. Sedangkan pikiran bawah sadar (subsconscious) adalah pikiran subjektif yang berisi tentang segala sesuatu yang berkaitan dengan emosi serta memori, ini bersifat irasional

Kedua pola fikir sadar dan bawah sadar inilah yang terus berinteraksi. Kedua pola fikir ini membagi tugasnya masing-masing yaitu, pikiran bawah sadar akan menjalankan apa yang telah dikesankan kepadanya melalui sistem kepercayaan yang lahir dari hasil kesimpulan nalar, dari pikiran sadar terhadap objek luar yang diamatinya. Hal ini terjadi karena, pikiran bawah sadar akan terus mengikuti kesan dari pikiran yang sadar, maka pikiran sadar diibaratkan seperti nahkoda sedangkan pikiran bawah sadar diibaratkan seperti awak kapal yang siap menjalankan perintah, terlepas perintah itu benar atau salah. Dalam hal ini pikiran sadar bisa berperan sebagai penjaga untuk melindungi pikiran bawah sadar dari pengaruh objek luar yang dapat berpengaruh negatif 12 .

Dengan memahami cara kerja akal pikiran tersebut, kita memahami bahwa pengendalian pikiran menjadi sangat penting. Dengan kemampuan kita dalam mengendalikan pikiran ke arah kebaikan, kita akan mudah mendapatkan apa yang kita inginkan.

\section{b. Proses Pembentukan Karakter}

Secara alami sejak lahir hingga berusia tiga tahun, atau mungkin hingga sekitar lima tahun, kemampuan menalar seorang anak belum terbentuk dengan sempurna, sehingga pikiran bawah sadar (subconscious mind) masih terbuka

$11 \mathrm{Mu}$ 'in. Fatchul. Pendidikan Karakter Konstruksi Teoretik dan Praktek (Jogjakarta: Ar-Ruzz Media 2011). hlm 27

12 Muin, Fathul, Op. Cit. hlm . 98

Al-Idarah: Jurnal Kependidikan Islam Vol. 8 No. 2, Desember 2018| 206 
dan menerima apa saja informasi dan stimulus yang dimasukkan ke dalamnya tanpa ada penyeleksian/penyaringan, fikiran bawah sadar yang di dapat anak itu bias dari orang tua dan lingkungan keluarga. Faktor lingkungan itulah pondasi awal terbentuknya karakter yang akan terbangun. Pondasi tersebut adalah yang akan menjadi kepercayaan tertentu bagi anak dan menjadi konsep dasar diri anak. Jika sejak kecil kedua orang tua selalu bertengkar, berkata kasar, dan memberikan hal negatif, maka seorang anak bisa mengambil kesimpulan sendiri bahwa perkawinan itu penderitaan. Tetapi, jika kedua orang tua selalu menunjukkan rasa saling menghormati dengan bentuk komunikasi yang akrab maka anak akan menyimpulkan ternyata pernikahan itu indah. Semua ini akan berdampak ketika sudah tumbuh dewasa.begitupun dengan keterampilan menulis, jika sejak kecil anak terbiasa di ajarkan berfikir kritis yang bersifat membangun terhadap suatu hal, maka bisa jadi anak akan terbiasa dengan pola fikir yang kritis13.

Selanjutnya, semua pengalaman hidup yang berasal dari lingkungan terdekat, sekolah, televisi, internet, buku, majalah, dan berbagai sumber lainnya menambah pengetahuan yang akan mengantarkan seseorang memiliki kemampuan yang semakin besar untuk dapat menganalisis dan menalar objek luar. Mulai dari sinilah, peran pikiran sadar (conscious) menjadi semakin dominan. Seiring perjalanan waktu, maka penyaringan terhadap informasi yang masuk melalui pikiran sadar menjadi lebih ketat sehingga tidak sembarang informasi yang masuk melalui panca indera dapat mudah dan langsung diterima oleh pikiran bawah sadar. Semakin banyak informasi yang diterima dan semakin matang sistem kepercayaan dan pola pikir yang akan terbentuk.

\section{Hubungan Menulis Kritis dengan Manajemen Karakter}

Sebenanya kemampuan menulis dapat kita asah sejak usia sedini mungkin. Anak yang memiliki bakat menulis sejak dini akan terlihat, anak tersebut dapat menuangkan ide-ide, atau perasaan yang ada dalam dirinya melalui tulisan yang ia buat. Jika sudah demikian maka untuk mengasah kemampuan menulis kritis pada anak akan lebih mudah. Sejalan dengan tujuan ini mari kita kaji apakah ada hubungan antara menulis dengan manajemen karakter pada peserta didik?.

Pentingnya kemampuan menulis dalam manajemen karakter tak lepas dari teori konstruksi pemikiran dan kurikulum. Kurikulum yang saat ini ada selalu menuntut untuk perubahan dalam diri peserta didik, utamanya adalah menginginkan peserta didik mampu memiliki sebuah pemikiran yang kritis, itu dapat kita lihat dan bandingkan dari stiap kurikulum yang terus berubah, jika dahulu metode belajar guru/ pendidik yang jadi tumpuan dalam proses belajar 
mengajar, maka saat ini semua terbalik, peserta didik sendiri yang menjadi sumber dalam proses belajar mengajar.

Hal ini tentunya menuntut peserta didik untuk semakin berfikir kritis dalam mengembangkan ide-ide dan gagasan kedalam tulisan14. Berdasarakan pemaparan di atas dapat kita tarik benang merah bahwa dari pembentukan karakter sejak anak dalam kandungan hingga usia sekolah bahwa sebagian besar anak akan membawa kebiasaan-kebiasaan yang di dapat dari lingkungan sekitar, termasuk lingkungan sekolah. Jika hal positif yang kita tanamkan sejak dini adalah ketrerampilan berbicara, maka anak akan terampil berbicara, sebaliknya jika anak di ajarkan untuk terampil menulis maka anak akan menguasai keterampilan menulis, dalam hal ini penulis membatasi dengan kajian menulis kritis. Salah satu tujuan utama pendidikan tinggi adalah mengembangkan pemikiran kritis tetapi dalam kenyataannya, mahasiswa belum mampu mengembangkan pemikiran kritis mereka hal ini menggambarkan betapa miskinnya pemikiran kritis mahasiswa

Situasi seperti ini mendorong lahirnya salah satu tujuan khusus pendidikan tinggi, yakni agar proporsi lulusan perguruan tinggi memiliki suatu kemampuan yang lebih tinggi daripada sekedar untuk berfikir secara kritis, yaitu dengan terampil, menulis kritis, berkomunikasi secara efektif. Dengan penguatan bekal keterampilan berfikir kritis tersebut, diharapkan akan tumbuh karakter kritis lainnya salah satunya mampu menyampaikan gagasan atau ide-ide yang bersifat membangun dengan kritis. Selain itu menulis kritis juga memiliki tujuan khusus yaitu mengungkapkan fakta-fakta, perasaan, sikap, dan isi pikiran secara jelas dan efektif kepada pembaca. Karena tidak semua orang mampu mengungkapkan hal-hal tersebut secara lisan di karenakan keterbatasan kemampuan berbicara. Dengan kegiatan menulis kritis siswa diharapkan dapat meningkatkan kecerdasan, mengembangkan daya inisiatif dan kreativitas, menumbuhkan keberanian dan mendorong kemauan, serta kemampuan untuk mengumpulkan informasi membentuk karakter yang kokoh sebagai seorang mahasiwa yang sudah sewajarnya berfikir kritis serta mampu mengungkapkan gagasannya lewat tulisan yang bernada kritis. 15 


\section{PENUTUP}

Pendidikan karakter bertujuan untuk menanamkan nilai dalam diri siswa dan pembaharuan tata kehidupan bersama yang lebih menghargai kebebasan individu. Tujuan jangka panjangnya tidak lain adalah mendasarkan diri pada tanggapan aktif kontekstual individu atas impuls natural social yang diterimanya, yang pada gilirannya semakin mempertajam visi hidup yang akan diraih lewat proses pembentukan diri secara terus menerus. Pendidikan karakter juga bertujuan meningkatkan mutu penyelenggaraan dan hasil pendidikan di sekolah yang mengarah pada pencapaian pembentukan karakter dan akhlak mulia peserta didik secara utuh, terpadu, dan seimbang sesuai sesuai dengan standar kompetensi lulusan. Untuk mencapai tujuan ini perlu ditanamkan nilai-nilai kritis untuk memperkuat karakter siswa di antaranya adalah keterampilan menulis kritis, dengan terbiasa menulis kritis maka terbentuklah karakter kuat dalam diri anak untuk belajar krtis dalam segala hal.

\section{DAFTAR PUSTAKA}

Waskito. 2010. Kamus Praktis Bahasa Indonesia. Jakarta: Kawah Media

Bahri Djamarah, Syaiful dan Aswan Zain, Strategi Belajar Mengajar. Jakarta Selatan: Rineka Cipta. 2013

Dalman. 2018. Keterampilan Menulis. Depok : Raja Grafindo

Mulyasa. 2011. Manajemen Berbasis Sekolah Konsep, Strategi, Dan Implementasi. Bandung : PT. Remaja Rosdakarya

Karwati, Euis, Priansa. 2015. Manajemen Kelas. Bandung: Alfabeta

Koesoema. Doni A. 2010. Pendidikan Karakter: Strategi Mendidik Anak di Zaman Global. Jakarta: Grasindo

Kompri. 2015. Manajemen Pendidikan. Bandung : Alfabeta

Mu'in. Fatchul. 2011. Pendidikan Karakter Konstruksi Teoretik dan Praktik. Jogjakarta: Ar-Ruzz Media

Rusman. 2009. Manajemen Kurikulum. Jakarta: Rajawali Press 